\title{
EFFECTS OF VARIABILITY IN THE POZZOLANIC PROPERTIES OF RICE HUSK ASH ON THE COMPRESSIVE STRENGTH OF CONCRETE
}

\author{
G. A. Akeke ${ }^{1,}{ }^{*}$, D. E. Ewa ${ }^{2}$ and F. 0. Okafor ${ }^{3}$ \\ 1, 3 DEPARTMENT OF CiVIL ENGINEERING UNIVERSITY OF NigERIA, NSUKKA, ENUGU STATE, NIGERIA \\ 2 Dept. of Civil Engineering Cross River University of TeChnology, Calabar, Cross River State, NiGERIA \\ E-mail addresses:1greatakeke@yahoo.com, 2esmondewa4sky@gmail.com,3fidelis.okafor@unn.edu.ng
}

\begin{abstract}
Rice husk ash (RHA) is an agro waste and a natural pozzolana which is rich in silica and found in abundance globally. This research considered the pozzolanic properties of RHA from Seven different sources in Nigeria (Ogoja, Abakaliki, Adani, Adikpo, Obubra, Makurdi and Vandikya). It is discovered that the elemental chemical composition of this natural pozzolan varies based on their location. Samples from Ogoja were found to have the highest pozzolanic properties followed by Abakaliki, Adani, Adikpo, Obubra, Makurdi and Vandikya. Their silica content was found to be84.55\%, 76.3\%, 70.12\%, 70.11\%, 64.67\%, 55.55\%, and 48.4\% respectively. Four out of the seven samples with the highest pozzolanic values were used as partial replacements for ordinary Portland cement at 5 , $10,15,20,25$, and 30\% replacement levels. Concrete mix ratio of 1:1.5:3 was adopted and the compressive strength values at 28 days were found to be in the range of $37-42 \mathrm{~N} / \mathrm{mm}^{2}$ at $5 \% R H A, 35-39.5 \mathrm{~N} / \mathrm{mm}^{2}$ at $10 \% R H A, 30$ $34.5 \mathrm{~N} / \mathrm{mm}^{2}$ at $15 \% \mathrm{RHA}, 27-29 \mathrm{~N} / \mathrm{mm}^{2}$ at $20 \% \mathrm{RHA}, 22-25.6 \mathrm{~N} / \mathrm{mm}^{2}$ at $25 \% \mathrm{RHA}$ and $21-24 \mathrm{~N} / \mathrm{mm}^{2}$ at $30 \% \mathrm{RHA}$ compared to the controlled sample with a strength value of $42.64 \mathrm{~N} / \mathrm{mm}^{2}$.
\end{abstract}

Keywords: Compressive Strength, Concrete, Rice Husk Ash (RHA), Variability.

\section{INTRODUCTION}

Concrete is the commonest material used in construction in most parts of the world with cement as a binder. This has placed a high demand on Cement with its attendant negative impact on the environment due to the Carbon dioxide (a greenhouse gas) emission into the atmosphere. This has therefore necessitated the need for research into locally available material for partial or full replacement of cement like RHA. This research has shows that the properties of RHA vary based on the location and their pozzolanic activity or efficacy is also affected by their elemental composition.

RHA is an agro waste found in abundance in most parts of the world and waste managers are seeking for ways of disposing off this material, which has been found to be a natural pozzolana. Pozzolanas are materials containing reactive silica and or Aluminium [1]. When the material is mixed with lime in powdered form and in the presence of water, it will set and harden like cement [2].
The quality and strength desired in concrete is fundamentally related to its compressive strength [3]. Compressive strength is the most convenient way of measuring and assessing the quality of hardened concrete using the formula of equation (1).

$$
F=\frac{P}{A}
$$

Where $\mathrm{P}$ is the crushing load and $\mathrm{A}$ is the cross sectional area of the cube or cylinder.

According to Narayan [4]. There is an increasing importance to preserve the environment in the present day world. RHA from the parboiling plants is posing serious environmental threat and ways are being thought of to dispose them. This material is a super pozzolana since it is rich in Silica and has about $85 \%$ to $90 \%$ Silica content and can be use as supplementary material in construction.

Narayan, [4] showed that by utilizing this pozzolanic materials even in small amounts (5\% to $10 \%$ cement replacements) can enhance the workability and impermeability of concrete mixes, as a result, the resulting concrete is highly durable and resistant to 
chemical attacks, abrasion and reinforcement corrosion. Pozzolana are not just "filler" but a strength and performance enhancing additives.

Report of [5] confirmed that RHA has a total percentage composition of Silicon dioxide $\left(\mathrm{SiO}_{2}\right)$, Iron III Oxide $\left(\mathrm{Fe}_{2} \mathrm{O}_{3}\right)$ and Aluminium Oxide $\left(\mathrm{Al}_{2} \mathrm{O}_{3}\right)$ to be $73.15 \%$ which is above the minimum requirement of $70 \%$ by the American Standard for Testing Materials (ASTM) C618-78 of 1978). According to the chemical analysis study carried out by [6], it was discovered that RHA and OPC are chemically similar.

According to [7], the principal binder in concrete is Portland cement, the production of which is a major contributor to greenhouse gas emissions. RHA is an agricultural waste and a good natural pozzolana, as it contains large amount of silica. When used in concrete as a supplement to OPC led to improved workability, reduced heat evolution, reduced permeability without any serious reduction in the strength values. Mauro [8] reported that the world rice harvest is estimated at 500 million tons per year. Twenty per cent of the grain is husk and $20 \%$ of the husk after combustion is converted to ash, a total of 20 million tons of ash can be obtained and the ash contains $92.99 \%$ silica oxide.

According to the study carried out by [9] on the use of RHA in concrete, it was further establish is that RHA is of 25 micron size, which serves as a filler to cement. They further established that "by using RHA in concrete as a replacement to OPC, the emission of greenhouse gasses can be decreased to a greater extent. As a result preserving the environment and reducing environmental pollution.

According to [10], the environmental pollution caused by the emission of $\mathrm{CO}_{2}$ into the atmosphere during the processing of clinker or limestone can be mitigated through the use of alternative fuels, the use of energy efficiency improvements in the cement plants, and the replacement of limestone-based clinker with other materials such as supplementary cementing materials $(\mathrm{scm})$ to reduce the use of Portland cement.

According to [11], the global increase in different construction methods and types, especially in Iran affects the environment adversely. On the head of construction materials, there is the most consumed material namely concrete. Production of Portland cement in addition to consuming fossil fuels and coal leads to the production of unwanted greenhouse gases and fine-grain materials which are pollutants. Therefore the use of natural pozzolana (RHA) as alternative cementitious materials should be encouraged to ensure environmental sustainability. In another hand, waste managers are faced with the problem of disposing agricultural waste example RHA which if put into effective use as a construction material will enhance its economic value. According to [12], utilizing RHA as a construction material will solve the problem of waste management, enhance environmental protection and sustainability and improve the economic value of RHA.

\section{MATERIALS AND METHODS}

\subsection{Cement}

Ordinary Portland cement (OPC) was used in which the composition and properties are in compliance with [13] IS 269: 1989.

\subsection{Fine Aggregate}

This research work was restricted to sand collected from the river. The sand was collected to ensure that there was no deleterious materials and prepared in accordance with [14] IS 383:1970.

\subsection{Coarse Aggregate}

In this research, granite of $5-20 \mathrm{~mm}$ maximum size was used. Proper inspection was carried out to ensure that it was free from deleterious materials as required by [14] IS 383:1970.

\subsection{Rice Husk Ash}

Rice Husk Ash (RHA) rich in silica was used in this project. The rice husks were gotten from four (4) different locations of Adani in Enugu state, Ogoja in CRS, Abakaliki in Ebonyi and Adikpo in Benue State. They were subjected to uncontrolled incineration and the ash collected and stored in dry area in the laboratory. Chemical analyses was conducted on the ashes to determine the elemental composition and pozzolanic properties of each ash in accordance with [15] IS 1489 (1):1991.

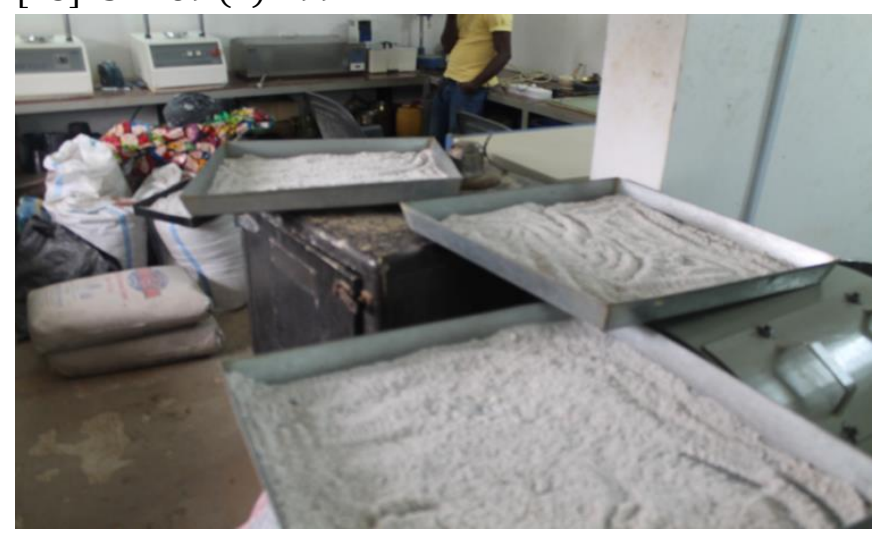

Figure 1. Showing RHA being Dried and Processed in the Laboratory. 
Concrete is a mixture of water, cement, aggregate (coarse and fine) and admixture. It is important that the materials remain uniformly distributed within the concrete mass during the various stages of handling and that full compaction is achieved and making sure that the characteristics of concrete which affect full compaction like consistency, mobility and compatibility are in conformity with relevant codes of practice.

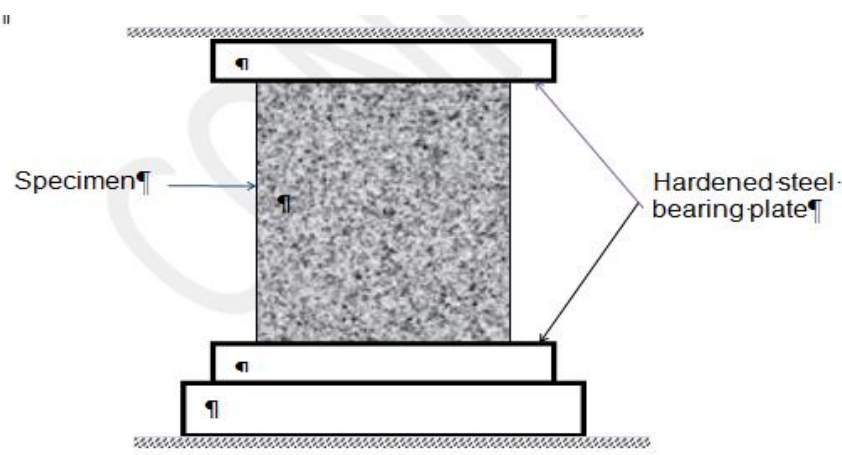

Figure 2 showing uniaxial compressive strength test of concrete

\subsection{Compressive strength test on cube}

The test was carried out in accordance with BSEN 206, 2001 Part 3. The samples were Prepared and concrete well mixed to achieve a homogenous mix, placed in the mould and vibrated in three layers. The samples were then demoulded after $24 \mathrm{hrs}$ and then cured at $20^{\circ} \mathrm{C}$ for $7,14,21$ and 28 days thereafter they were tested or crushed by a constant rate of stress increase of $15 \mathrm{~N} / \mathrm{mm}^{2}$ immediately after removal from the curing tank, see Figure 3. The cube test gives information for the determination of the characteristic strength of concrete which is given as the strength below which not more than $5 \%$ of the tests results would fall. The samples were prepared and tested as shown in Figure 2.

\section{RESULTS AND DISCUSSIONS}

\subsection{Physical properties of materials}

The specific gravity of RHA was found to be in the range of 1.67 to 1.94 for the various locations considered, sand (fine aggregate) was 2.4 while that of coarse aggregate was 2.89. Table 1 presents the particle size distribution of RHA and OPC, the results confirms that RHA is finer than OPC which agrees with other researchers.

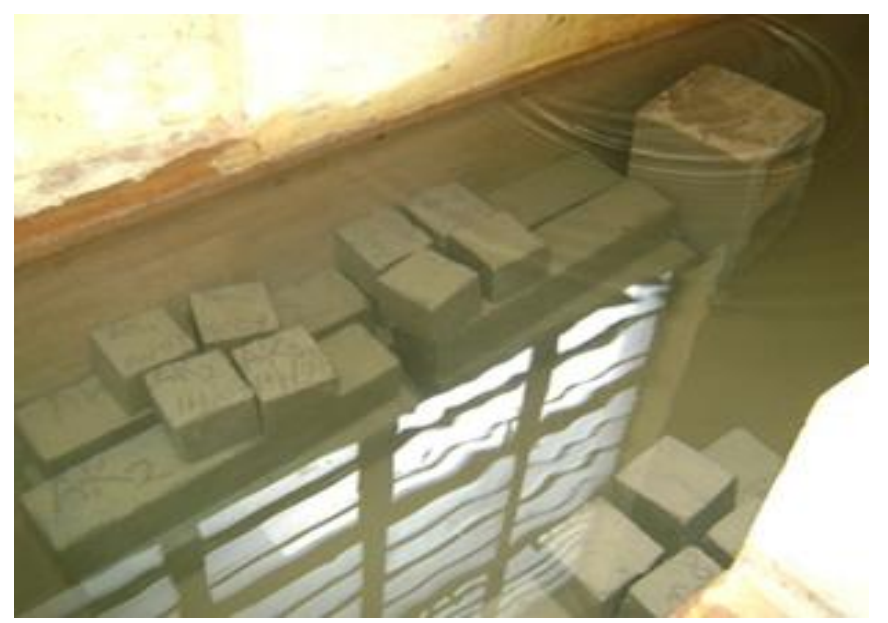

(a)

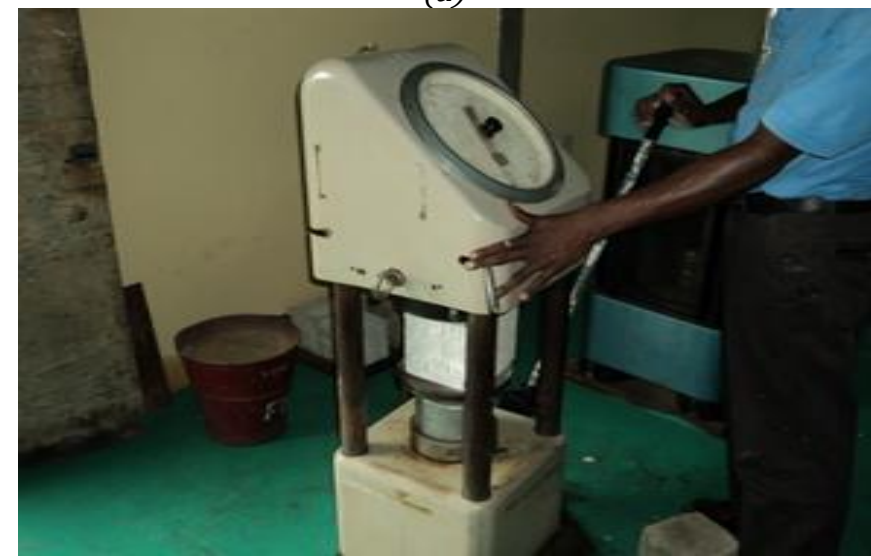

(b)

Figure 3: (a) Test samples in the curing tank (b) Some of the test samples after removal from the curing tank

Table 1: Show the particle size distribution results of the various RHA and Cement.

\begin{tabular}{|c|c|c|c|c|c|c|c|c|}
\hline $\begin{array}{l}\text { Sieve } \\
\text { Size }\end{array}$ & $\begin{array}{l}\text { \%Passing } \\
\text { Adani }\end{array}$ & $\begin{array}{l}\text { \%Passing } \\
\text { Abakaliki }\end{array}$ & $\begin{array}{l}\text { \% Passing } \\
\text { Ogoja }\end{array}$ & $\begin{array}{l}\text { \% Passing } \\
\text { Obubra }\end{array}$ & $\begin{array}{l}\text { \% Passing } \\
\text { Adikpo }\end{array}$ & $\begin{array}{l}\text { \% Passing } \\
\text { Vandikiya }\end{array}$ & $\begin{array}{l}\text { \% Passing } \\
\text { Makurdi }\end{array}$ & $\begin{array}{l}\text { \% Passing } \\
\text { OPC }\end{array}$ \\
\hline 2.36 & 100 & 100 & 100 & 100 & 100 & 100 & 100 & 100 \\
\hline 1.18 & 100 & 100 & 100 & 100 & 100 & 100 & 100 & 100 \\
\hline 600 & 94 & 98 & 93.2 & 90 & 100 & 100 & 98 & 100 \\
\hline 425 & 80 & 90 & 85 & 85 & 90 & 95 & 82 & 100 \\
\hline 300 & 50 & 55 & 55 & 60 & 60 & 52 & 51 & 80 \\
\hline 212 & 45 & 45 & 43.6 & 40 & 50 & 49.5 & 41 & 35 \\
\hline 150 & 25 & 30 & 27.4 & 25 & 30 & 35 & 30 & 22 \\
\hline 63 & 5 & 4 & 7.4 & 8 & 9 & 7.5 & 5.5 & 4 \\
\hline Pan & 0 & 0 & 0 & 0 & 0 & 0 & 0 & 0 \\
\hline
\end{tabular}


Table 2: Results of chemical analysis on RHA and OPC

\begin{tabular}{|c|c|c|c|c|c|c|c|c|c|}
\hline \multirow{2}{*}{$\mathrm{S} / \mathrm{N}$} & \multirow{2}{*}{ SAMPLE/LOCATIONS } & \multicolumn{8}{|c|}{ ELEMENTAL COMPOSITION IN \% } \\
\hline & & $\mathrm{ZnO}$ & $\mathrm{SiO}_{2}$ & $\mathrm{CaO}$ & $\mathrm{Fe}_{2} \mathrm{O}_{3}$ & $\mathrm{~K}_{2} \mathrm{O}$ & $\mathrm{MnO}$ & $\mathrm{MgO}$ & $\mathrm{Na}_{2} \mathrm{O}$ \\
\hline 1 & $\begin{array}{l}\text { UNICEM CEMENT } \\
\text { (Control) }\end{array}$ & 0.12 & 23.50 & 65.20 & 3.40 & 0.40 & 0.18 & 1.35 & 0.30 \\
\hline 2 & ADANI-ES & 0.60 & 70.20 & 0.20 & 0.05 & 0.66 & 0.57 & 0.52 & 0.52 \\
\hline 3 & $\begin{array}{l}\text { OGOJA-CRS } \\
\text { E0477210, N0729822 }\end{array}$ & 0.75 & 84.50 & 0.30 & 0.25 & 0.69 & 0.43 & 0.45 & 0.51 \\
\hline 4 & $\begin{array}{l}\text { VANDIKYA-BS } \\
\text { E0507062, N0750072 }\end{array}$ & 0.60 & 68.40 & 0.23 & 0.21 & 0.73 & 0.60 & 0.50 & 0.25 \\
\hline 5 & $\begin{array}{l}\text { ABAKALIKI- EBS } \\
\text { E0405465, N0697514 }\end{array}$ & 0.20 & 76.30 & 0.25 & 0.09 & 0.27 & 0.20 & 0.03 & 0.16 \\
\hline 6 & $\begin{array}{l}\text { ADIKPO-BS } \\
\text { E0525472, N0760211 }\end{array}$ & 0.37 & 70.10 & 0.28 & 0.18 & 0.41 & 0.27 & 0.20 & 0.22 \\
\hline 7 & $\begin{array}{l}\text { OBUBRA-CRS } \\
\text { E0418329, N0661377 }\end{array}$ & 0.45 & 74.70 & 0.31 & 0.23 & 0.48 & 0.32 & 0.44 & 0.38 \\
\hline 8 & MAKURDI & 0.54 & 70.60 & 0.34 & 0.15 & 0.44 & 0.52 & 0.36 & 0.41 \\
\hline
\end{tabular}

Table 3: Density values for various RHA concrete mixes in $\mathrm{kg} / \mathrm{m}^{3}$

\begin{tabular}{lccccccc}
\hline \multirow{2}{*}{ Source of concrete mixes } & Age & \multicolumn{7}{c}{ Percentage Replacement with RHA } \\
\cline { 2 - 7 } & 3 & $5 \%$ & $10 \%$ & $15 \%$ & $20 \%$ & $25 \%$ & $30 \%$ \\
\hline \multirow{3}{*}{ Ogoja, Cross River State } & 7 & 2342.91 & 2304.59 & 2266.57 & 2272.59 & 2214.62 & 2214.62 \\
& 14 & 2364.74 & 2317.33 & 2316.44 & 2288.69 & 2262.12 & 2262.12 \\
& 21 & 2357.43 & 2335.70 & 2331.26 & 2317.04 & 2272.10 & 2272.10 \\
& 28 & 2326.22 & 2350.72 & 2343.70 & 2274.17 & 2296.20 & 2296.20 \\
\hline \multirow{3}{*}{ Abakaliki, Ebonyi State } & 3 & 2326.91 & 2315.56 & 2347.95 & 2284.44 & 2282.47 & 2222.72 \\
& 7 & 2338.27 & 2301.73 & 2378.37 & 2271.80 & 2215.80 & 2234.07 \\
& 14 & 2365.33 & 2325.73 & 2328.69 & 2357.83 & 2283.46 & 2241.48 \\
& 21 & 2359.41 & 2341.04 & 2333.83 & 2335.21 & 2300.84 & 2257.78 \\
Adani, Enugu State & 28 & 2340.64 & 2371.65 & 2339.06 & 2307.75 & 2324.74 & 2258.47 \\
\hline & 3 & 2325.43 & 2239.60 & 2286.62 & 2282.86 & 2269.63 & 2223.41 \\
& 7 & 2305.28 & 2238.02 & 2292.74 & 2273.58 & 2214.62 & 2228.84 \\
& 14 & 2360.59 & 2359.90 & 2342.32 & 2288.69 & 2262.12 & 2242.57 \\
& 21 & 2324.05 & 2277.33 & 2327.31 & 2317.04 & 2272.10 & 2253.53 \\
& 28 & 2347.75 & 2364.15 & 2345.88 & 2284.05 & 2299.16 & 2263.70 \\
\hline & 3 & 2344.30 & 2293.73 & 2307.36 & 2282.86 & 2269.63 & 2223.41 \\
& 7 & 2340.94 & 2301.93 & 2267.06 & 2272.59 & 2214.62 & 2228.84 \\
& 14 & 2362.57 & 2319.01 & 2318.42 & 2288.69 & 2262.12 & 2242.57 \\
& 21 & 2356.44 & 2335.31 & 2331.65 & 2317.04 & 2272.10 & 2253.53 \\
& 28 & 2324.25 & 2345.68 & 2344.69 & 2274.17 & 2296.20 & 2263.70 \\
\hline
\end{tabular}

RHA is a natural pozzolana with very high Silica content of $84.5 \%$ and other chemical oxide composition similar to that of cement as shown in Table 2, making it a supplementary material to OPC. Table 3 show the densities for various RHA concrete mixes and percentage replacements.

The results show that RHA concrete is denser than normal concrete confirming the advantage of its function as a filler in cement since its grain sizes are smaller than that of cement making RHA concrete less porous.

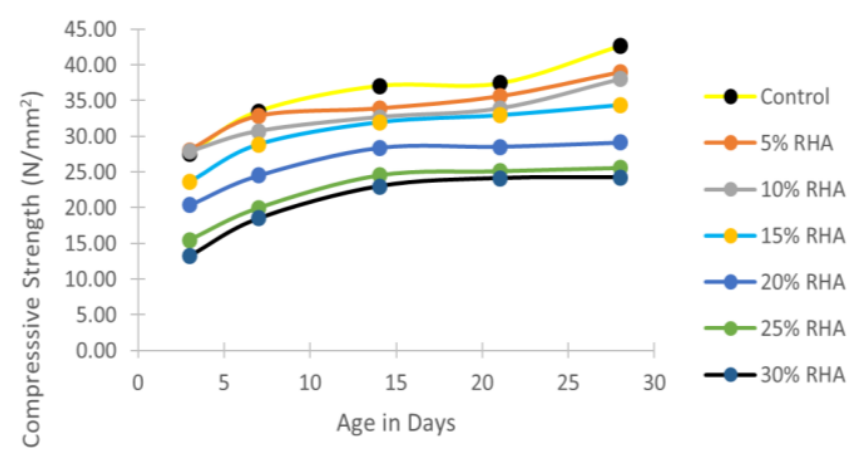

Figure 4: The relationship between compressive strength and age for RHA concrete from Abakaliki $E B S$. 


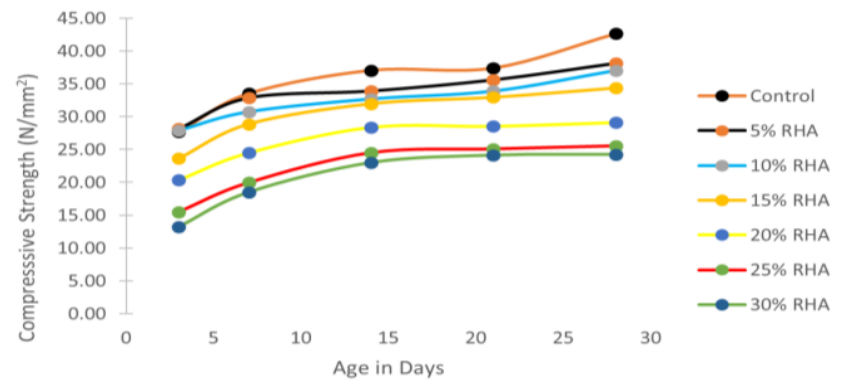

Figure 5:The relationship between compressive strength and age for RHA concrete from Adani ES

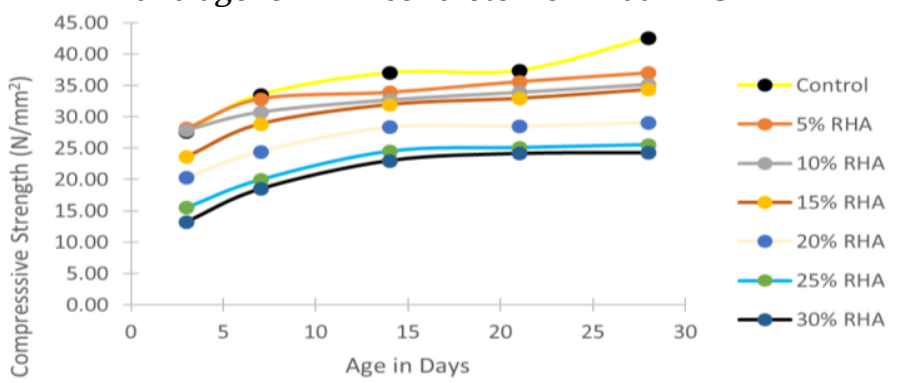

Figure 6: The relationship between compressive strength and age for RHA concrete from Adikpo BS

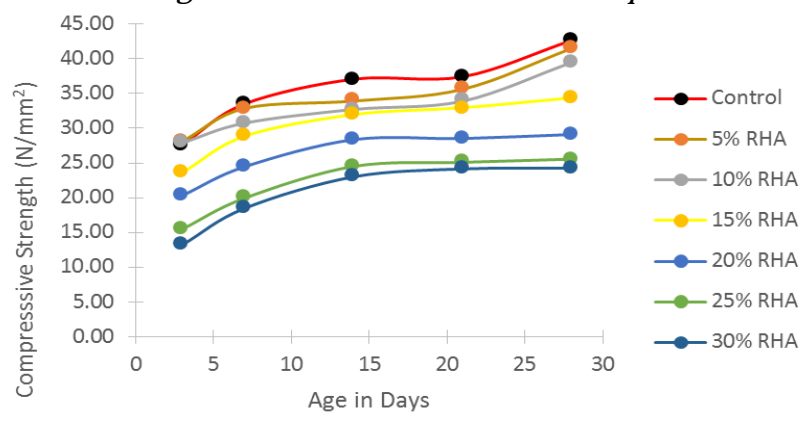

Figure 7: The relationship between compressive strength and age for RHA concrete from Ogoja CRS.

Concrete cubes were prepared from different samples of RHA concrete using 5\%, 10\%, 15\%,20\%,25\% and 30\% replacements of ordinary Portland cement. The results are graphically presented in Figures 4 to 7 .

The effect of RHA on the compressive strength of concrete shows incremental characteristics in strength with values ranging from 24.27 to $41.48 \mathrm{~N} / \mathrm{mm}^{2}$ with variability in strength of samples from different locations. It can be seen that the compressive strength compares favourably with the controlled concrete at 5 to $20 \%$ replacements, this implies that reasonable strength of concrete can be achieved with a $20 \%$ savings on the cost of OPC.

\section{CONCLUSION}

From the results and findings, it has been established that there is variability in the chemical composition of RHA based on location and this affects its efficacy or pozzolanic activity when used to partially replace cement. The compressive strength values increased in the same proportion as the chemical composition and decreases with an increase in the percentage of RHA from $25-30 \%$ replacements. With $15 \%$ RHA replacement, adequate compressive strength can be achieved. RHA is a natural pozzolana and an annual renewable source of silica.

\section{REFFERENCES}

[1] Obam, S. 0. "Compressive Strength of RHA Concrete", Nigerian Journal of Technology, Vol. 25, Number 2, pp 110, 2006.

[2] ASTM Standard C311. Standard Test Methods for Sampling and testing Fly Ash or Natural Pozzolans for use in Portland cement concrete. West Conshohocken, Pennsylvania, 1994.

[3] Nevile, A.M and Brooks, J.J, Concrete Technology, Singapore: Longman Ltd., 1990.

[4] Narrayan P. S. "Rice Husk Ash used in Making of Concrete Canoe" Michigan Technological University, 1400 Townsend Dr. Houghton Mi 49931, 2005.

[5] Oyetola E. B. and Abdullahi M. "The Use of Rice Husk Ash in Low - Cost Sandcrete Block Production", Leonardo Electronic Journal of Practices and Technologies. Issue 8, 01-06, pp. 58 - 70. 2006.

[6] G. A Habeeb, M. M Fayyaah. "Rice Husk Ash Concrete: the Effect of RHA Average Particle Size on Mechanical Properties and Drying Shrinkage", Australian Journal of Basic Applied Sciences, Vol 3(3) pp 1616-1622, 2009.

[7] Ramarao, G.V and Seshagiri Rao. "HPC with RHA as mineral Admixture", Indian Concrete Institute Journal. Vol. 4-6, pp 17-21, 2003.

[8] Mauro, M. Tashima, Carlos, A. R. da Silva, Jorge L. Akasaki, Michele Beniti Barbosa. "The Possibility of Adding the Rice Husk Ash (RHA) to the Concrete", Civil Engineering Conference, Brazil May, pp 1-9, 2005.

[9] Padma Rao, P. A. Pradhan Kumar and B. Bhaskar Singh. "A Study on Use of Rice Husk Ash in Concrete". International Journal of Education and Applied Research, Vol. 4, Issue SPL-2, 2014.

[10] Sumreng Rukzon, Prinya Chindaprasirt and Rattana Mahachai. "Effect of Grinding on Chemical and Physical Properties of Rice Husk Ash". International Journal of Minerals, Metallurgy and Materials, Vol. 16, Number 2, Pp 242, 2009.

[11] Ajay Kumar,Kalyani Mohanta, Devendra Kumar and Om Parkash. "Properties and Industrial Applications of Rice husk". International Journal of Emerging Technology and Advanced Engineering. Vol. 2, pp 86-90, 2012.

[12] Akeke, G.A, Ephraim, M.E, Akobo I.Z.S and Ukpata, J.O. "Structural Properties of RHA", International Journal of Engineering and Applied Sciences, Vol.3 Number3. Pp 57-62, 2012.

[13] Specification for Ordinary Portland Cement 33 grade. Indian standard, 1989.

[14] Specification for Coarse and Fine Aggregate for Natural Sources. Indian standard, 1970.

[15] Specification for Portland Pozzolana Cement Part 1 FlyAsh based, 1991. 